\title{
ANALGESIC EFFECTS OF THE AQUEOUS LEMON VERBENA EXTRACT IN RATS
}

\author{
Received June 7, 2014
}

\begin{abstract}
Lemon verbena (vervain, LV) is used in traditional folk medicine as a remedy against asthma, spasms, cold, fever, pain of different genesis, insomnia, etc., but its effects have not been examined experimentally. We studied effects of an aqueous extract of leafs of this plant on the parameters of nociception-related tests, tail-flick, and writhing ones. The first aqueous extract of LV leafs was prepared and dried. Wistar rats were randomly divided into seven experimental groups, which received i.p. injections of saline (control), LV extract (10, 100, 500, and $1000 \mathrm{mg}$ of dry substance per $1 \mathrm{~kg}$ of the body mass), morphine, and $1000 \mathrm{mg} / \mathrm{kg}$ of the $\mathrm{LV}$ extract + naloxone. Injections of 500 and $1000 \mathrm{mg} / \mathrm{kg}$ of the extract significantly increased the tail-flick latency, as compared to that in the control group $(P<0.001)$. The number of writhings per one hour decreased after injections of the extract $(100-1000 \mathrm{mg} / \mathrm{kg})$. The maximum analgesic effects of the extract were comparable with those of morphine $(10 \mathrm{mg} / \mathrm{kg})$. Naloxone completely abolished the effect of the LV extract in the tail-flick test and partly suppressed such action in the writhing test. Thus, our experiments demonstrated noticeable anti-nociceptive effects of the aqueous LV extract; possibilities for application of this extract or its derivatives in pain management should be examined.
\end{abstract}

Keywords: lemon verbena, aqueous extract, analgesic effects, tail-flick test, writhing test.

\section{INTRODUCTION}

Search for effective analgesic agents having minimum side effects is an important task in neuropharmacology and neurophysiology $[1,2]$. At present, a number of means (mostly plant-derived) used in traditional folk medicine are subjected to intense research from this aspect. Such studies inevitably include accurate experimental testing of the respective capabilities of the respective remedies and tempts to elucidate biochemical and pharmacological mechanisms of the effects of active constituents of such means.

Lemon verbena (LV, Aloysia citroiodora, Lippia citroiodora Kunth, or Verbena triphylla; there are some other synonyms) is a perennial shrub belonging to the family of Verbenaceae. It is native to Southwestern America, brought to Europe by the Spanish and Portuguese in the 17 th century and cultivated for its oil [3]. It has been traditionally used in folk medicine as a remedy in treatments of asthma, spasms,

\footnotetext{
1 Neurophysiology Research Center, Hamadan University of Medical Sciences, Hamadan, Iran

Correspondence should be addressed to S. Shahidi

(e-mail: siamakshahidi@yahoo.com).
}

cold, fever, flatulence, colic, indigestion, insomnia, anxiety, and headache $[4,5]$. Its constituents were demonstrated to exert antioxidant effects [6-8]. At the same time, the effects of remedies prepared from LV have not been studied experimentally until now.

We tried to estimate quantitatively the effects of the aqueous extract of LV in extensively used nociceptionrelated tests, tail-flick and writhing ones, in adult male rats.

\section{METHODS}

Preparation of the Extract. Dried LV leafs were bought from the Mehr Giahe Kosar Company (Medicinal Plants Company) in Iran-Shiraz. Leafs were chopped by an electrical grinder; $500 \mathrm{~g}$ of the material were soaked into 2.01 of distilled water for $12 \mathrm{~h}$ at room temperature. The extract was filtered through filter paper (Whatman, Cat No 1442 125), got dry in a hot air oven $\left(50^{\circ} \mathrm{C}\right)$, and turned into powder. The obtained powder was stored in a refrigerator. For injections, the required amounts of dry extract powder were weighed and dissolved in normal saline. 
Experimental Groups. Male Wistar rats (180-200 g) were bought from the Pasteur Institute of Iran, housed in groups of three in polypropylene cages with free access to water and food ad libitum, and kept in a room under controlled conditions $\left(24 \pm 1^{\circ} \mathrm{C}\right.$ and a 12/12 h light/dark cycle).

The rats were randomly divided into seven experimental groups ( $n=8$ in each). Animals of the control group received i.p. normal saline $(0.5 \mathrm{ml})$, those of four LV groups were i.p. injected with 10, 100,500 , and $1000 \mathrm{mg} / \mathrm{kg}$ of the extract; the morphine group received $10 \mathrm{mg} / \mathrm{kg}$ morphine, and the 7 th group was injected with naloxone $(4 \mathrm{mg} / \mathrm{kg})+\mathrm{LV}$ extract (1000 mg/kg).

\section{Evaluation of Anti-Nociceptive Activity.}

Tail-Flick Test. A standard technique of this test was used. The tail flick latency (TFL) was measured as the time interval between the beginning of application of radiant heat from an infrared stimulator (tail-flick apparatus) to the rat's tail $(5-8 \mathrm{~cm}$ from the tip) and the moment of tail withdrawal. The intensity of radiant heat was adjusted to establish the TFL value of 2-3 sec. The baseline latency was obtained using the mean of three similar consecutive measurements. To avoid tissue damage, a cut-off time of $10 \mathrm{sec}$ was set $[9,10]$.

The measurements were performed before and 20 min after the treatment with normal saline (control group), extract (four experimental groups), or morphine. In the naloxone + LV extract group, the TFL was first measured; then naloxone and, 10 min later, the LV extract were injected i.p., and, finally, the TFL was measured again 20 min later. In all cases, means of three measurements were taken into consideration.

Writhing Test. Thirty minutes after the treatment with saline or LV extract, $1 \mathrm{ml}$ of $1 \%$ acetic acid solution was injected i.p. into experimental rats. Then, the animals were placed immediately into a glass box, and the number of abdominal constrictions (writhings) was counted for $1 \mathrm{~h}$. The rats with a decreased number of writhings were considered protected from nociception $[11,12]$.

Statistical Analysis. Numerical data in the groups were compared by one-way analysis of variance (ANOVA) followed by the Tukey post-hoc test. The results are expressed below as means \pm s.e.m. and $P<0.05$ was considered as significant in intergroup comparisons.

\section{RESULTS}

Tail-Flick Test. There were no significant differences between the TFL values before LV or morphine injections among the experimental groups $\left(\mathrm{F}_{(6,49)}=3.120, P>0.05\right)$. However, the significant between-group differences in the TFL appeared after treatment $\left(\mathrm{F}_{(6,49)}=62.412, P<0.001\right)$. The respective index showed no significant differences after injections of the LV extract in the doses of 10 and $100 \mathrm{mg} / \mathrm{kg}$. The dose $500 \mathrm{mg} / \mathrm{kg}$, however, induced highly significant prolongation of the TLF $(P<$ $<0.001$, as compared to the control). At the dose of $1000 \mathrm{mg} / \mathrm{kg}$, the TLF was about three times longer than that in the control $(P<0.001)$ and was nearly equal to that observed after injection of a "standard" opioid analgesic, morphine. Preliminary injection of the opioid receptor antagonist naloxone resulted in practically complete removal of the effect of $1000 \mathrm{mg} / \mathrm{kg}$ of the LV extract $(P>0.05$ in comparison with the control; Fig. 1).

Writhing Test. Injections of 100 to $1000 \mathrm{mg} / \mathrm{kg}$ of the LV extract provided significant decreases

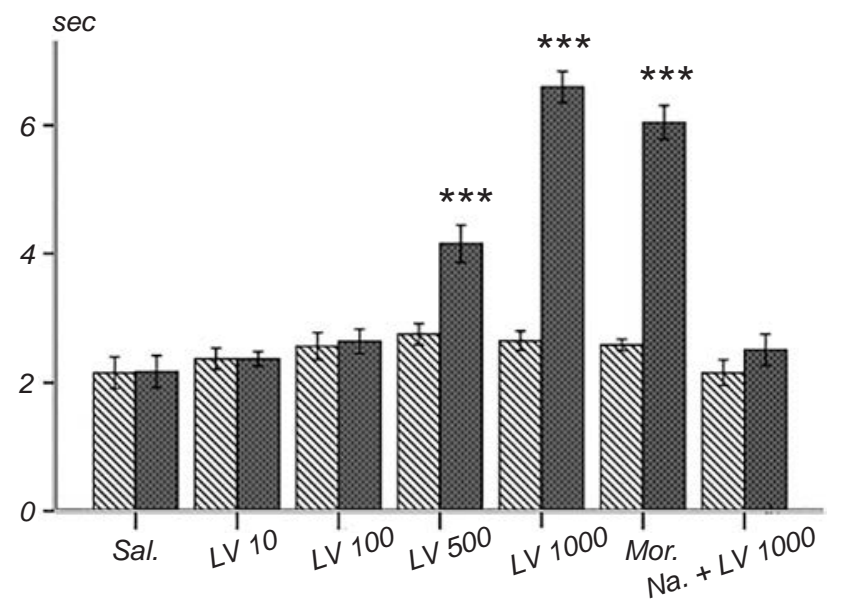

F i g. 1. Latencies, sec, of the tail-flick responses before (dashed columns) and $20 \mathrm{~min}$ after (filled columns) the treatment with normal saline (contr.), lemon verbena extract (LV; 10, 100, 500, and $1000 \mathrm{mg} / \mathrm{kg}$ ), morphine (Mor., $10 \mathrm{mg} / \mathrm{kg}$ ), and naloxone + + LV extract $(1000 \mathrm{mg} / \mathrm{kg}) ; n=8$ in each group; intragroup means \pm s.e.m. values are shown. ${ }^{* * * P} P<0.001$, as compared to the control.

Р и с. 1. Значення латентного періоду (c) реакцій відсмикування хвоста перед та через 20 хв після введення тестованих агентів (заштриховані та чорні стовпчики відповідно). 
in the number of writhings within the test period $\left(60 \mathrm{~min} ; \mathrm{F}_{(6,49)}=34.361, P<0.001\right)$. At the first of the mentioned doses, the writhing number corresponded to $42 \%$ of that in the control (saline) group $(P<0.001)$. Greater doses of the extract $(500$ and $1000 \mathrm{mg} / \mathrm{kg}$ ) provided nearly complete inhibition of writhing movements induced by visceral pain after acetic acid test injections $(P<0.001$ in both cases). Injections of morphine provided nearly the same effect $(P<0.001)$. The smallest of the extract doses used $(10 \mathrm{mg} / \mathrm{kg})$ exerted no significant effect on the results of the writhing test $(P>0.05)$. Injections of naloxone made before introductions of $1000 \mathrm{mg} / \mathrm{kg}$ of the LV extract resulted in significant $(P<0.01)$ suppression of the analgesic effect of this extract, but this suppression was not complete; the number of writhings during the test period corresponded to $62 \%$ of the respective index in the control (Fig. 2).

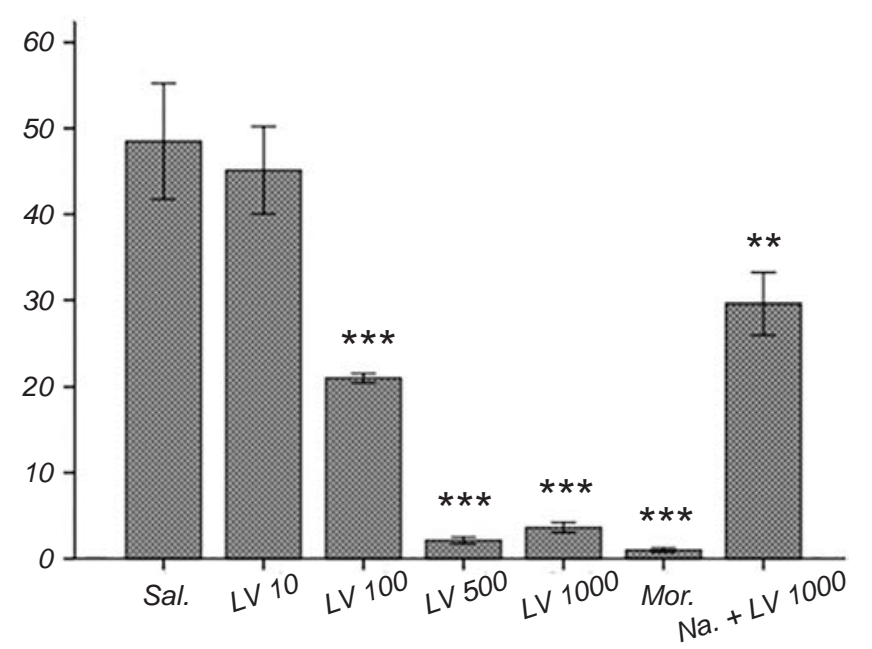

F i g. 2. Effects of administration of normal saline, different doses of lemon verbena (LV) extract, morphine, and naloxone $+\mathrm{LV}$ extract on the number of acetic acid-induced writhings within a $60 \mathrm{~min}$ observation period. $* * P<0.001, * * P<0.01$, as compared to the control. Other designations are similar to those in Fig. 1.

P и с. 2. Впливи введення фізіологічного розчину, водного екстракту листя лимонної вербени (ЛВ) у різних дозах, морфіну та налоксону + екстракт ЛВ на кількість «корчів» протягом 60 хв спостереження.

\section{DISCUSSION}

The results of our study indicated that the aqueous LV extract is capable of exerting rather intense and highly significant antinociceptive effects in both tail-flick and writhing tests. In the former test, acute pain results from activation of high-threshold thermonociceptors localized in the skin of the rat's tail. Results of the writhing test reflect generalized motor reactions induced by transient visceral pain developing after stimulation of visceral chemonociceptors by the acetic acid solution. Both tail-flick and writhing tests are used to detect the actions of central and peripheral analgesics. It should be noted that results of the tail-slick test are more sensitive to centrally acting analgesics.

The nociceptive effect in the above test is relatively short-lasting and is intensely influenced by agonists of $\mu$-opioid receptors responsible for analgesia in acute pain models. Therefore, it is believed that agents effective in this test exert their influences predominantly through $\mu$-opioid receptors [13, 14]. Our observations show that the analgesic effect of the aqueous LV extract is nearly fully prevented by pretreatment with the opioid antagonist naloxone; thus, in the tail-flick test this extract predominantly affects the opioid system.

The situation is somewhat different in the writhing test. Intraperitoneal administration of acetic acid results in the release of prostaglandins (like PGE2 and PGF $2 \alpha$ ) and sympathomimetic mediators; their levels are increased in the peritoneal fluid of the acetic acid-injected rat [15]. Abdominal constrictions produced after administration of acetic acid are related to sensitization of nociceptors to prostaglandins [16]. Thus, it is possible that the effect of the LV extracts is also based on inhibition of synthesis and/or release of prostaglandins. It was reported that the leaves of LV are rich in flavonoids and aldehydes (in particular, citral and citronellal) [4]. Flavonoids are well-known agents exerting anti-inflammatory and analgesic effects; furthermore, their effect on prostaglandins has been proved [17]. It seems probable that a part of the analgesic effect of the LV extract is related to a compound called verbascoside. The latter is a phenylpropanoid glycoside isolated from a few medicinal plants of different families, in particular, those of Verbenaceae including Lippia citriodora [1820]. In previous studies, noticeable anti-inflammatory and analgesic effects of verbascoside have been welldocumented [18]. It has also been reported that the analgesic effect of verbascoside is not prevented by pretreatment with the opioid antagonist naloxone; the effects of verbascoside do not require activation of the opioid system [18].

Therefore, administration of the aqueous LV extract exerts clearly pronounced dose-dependent analgesic effects in both tail-flick and writhing tests 
in rats. A part of the analgesic effects of this extract is due to activation of the opioid system. It can be suggested that the extract of LV may be considered a complementary analgesic mean counteracting pain of different geneses. At the same time, it should be noted that significant analgesic effects were provided by rather high doses of the extract. Thus, it seems that further research directed toward isolation of most effective constituents of such extracts is expedient; this, probably, can help to obtain some effective LVbased means usable in clinics.

Acknowledgment. This work includes a part of the MSc thesis and was supported by the grant No. 9207232346 from the Hamadan University of Medical Sciences (Iran).

All experimental procedures were done according to the Guide for care and use of laboratory animals published by the United States National Institutes of Health (NIH Publication No. 85-23, revised 1985).

The authors, M. Veisi, S. Shahidi, A. Komaki, and A. Sarihi, declare that there were no conflicts of any kind relating to commercial or financial relations, relations with organizations or persons, which could in any way be associated with the investigation, and with the relationship of the co-authors of the article.

\section{Beїсі ${ }^{1}$, C. Шахіді ${ }^{1}$, A. Комакі $^{1}$, A. Сарixi $^{1}$}

\section{АНАЛГЕТИЧНА ДІЯ ВОДНОГО ЕКСТРАКТУ ЛИМОННОЇ ВЕРБЕНИ У ЩУРІВ}

\author{
${ }^{1}$ Дослідницький центр із нейрофізіології при Хамадан- \\ ському медичному університеті (Іран). \\ Р е $з$ ю м е
}

Лимонна вербена (ЛВ) використовується в традиційній народній медицині як засіб проти астми, спазмів, застуди, лихоманки, болю різного походження, безсоння і т. п., проте її ефекти не досліджувались експериментально. Ми вивчали дію водного екстракту листя цієї рослини на параметри тестів, пов'язаних із ноцицепцією, - тесту відсмикування хвоста та тесту «кислотних корчів». Готували перший водний екстракт із листя ЛВ та дегітратували його. Досліди були проведені на семи експериментальних групах щурів лінії Вістар; тварини цих груп отримували внутрішньоочеревинні ін'єкції фізіологічного розчину (контроль), ЛВ-екстракту в чотирьох дозах $(10,100,500$ та 1000 мг сухої речовини на 1 кг маси тіла), морфіну та екстракту ЛВ (1000 мг/кг) із попередньою ін'єкцією налоксону. Ін'єкції екстракту в дозах 500 та 1000 мг/кг призводили до істотного збільшення латентного періоду реакції відсмикування хвоста порівняно з аналогічним показником у контролі $(P<0.001)$. Кількість «корчів» у відповідному тесті протягом
1 год істотно зменшувалася після ін'єкцій екстракту в дозах від 100 до 1000 мг/кг. Максимальні аналгетичні ефекти були близькими до таких після ін'єкцій морфіну (10 мг/кг). Налоксон повністю усував ефекти екстракту ЛВ у тесті відсмикування хвоста, але лише частково пригнічував відповідну дію в тесті «корчів». Отже, результати наших експериментів показали, що водний екстракт листя ЛВ має відчутну антиноцицептивну дію; можливості застосування цього екстракту або його похідних у контролі болю мають бути досліджені в подальшому.

\section{REFERENCES}

1. H. Breivik, P. C. Borchgrevink, S. M. Allen, et al., "Assessment of pain", Br. J. Anaesth., 101, No. 1, 17-24 (2008).

2. D. J. Debono, L. J. Hoeksema, and R. D. Hobbs, "Caring for patients with chronic pain: pearls and pitfalls," J. Am. Osteopath. Assoc., 113, No. 8, 620-627 (2013).

3. M. Roberts, A-Z of Herbs: Identifying Herbs, How to Grow Herbs, the Uses of Herbs, Struik (2000).

4. P. C. S. Gomes, H. R. C. Oliveira, A. M. S. Vicente, and M. F. Ferreira, "Production, transformation and essential oils composition of leaves and stems of lemon verbena [Aloysia triphylla (L'Herit.) Britton] grown in Portugal," Rev. Bras. Pl. Med., 8, 130-135 (2006).

5. M. E. Pascual, K. Slowing, E. Carretero, et al., "Lippia: traditional uses, chemistry and pharmacology: a review," $J$. Ethnopharmacol., 76, No. 3, 201-214 (2001).

6. L. Carrera-Quintanar, L. Funes, E. Viudes, et al., "Antioxidant effect of lemon verbena extracts in lymphocytes of university students performing aerobic training program," Scand. J. Med. Sci. Sports, 22, No. 4, 454-461 (2010).

7. L. Funes, L. Carrera-Quintanar, M. Cerdán-Calero, et al., "Effect of lemon verbena supplementation on muscular damage markers, proinflammatory cytokines release and neutrophils' oxidative stress in chronic exercise," Eur. J. Appl. Physiol., 111, No. 4, 695-705 (2011).

8. P. Valentão, E. Fernandes, F. Carvalho, et al., "Studies on the antioxidant activity of Lippia citriodora infusion: scavenging effect on superoxide radical, hydroxyl radical and hypochlorous acid," Biol. Pharm. Bull., 25, No. 10, 1324-1327 (2002)

9. S. Shahidi, A. Bathaei, and P. Pahlevani, "Antinociceptive effects of Valeriana extract in mice: Involvement of the dopaminergic and serotonergic systems," Neurophysiology, 45, Nos. 5/6, 448-452 (2013).

10. S. Shahidi, M. Mahmoodi, and N. Farahmandlou, "Antinociceptive properties of hydro-alcoholic extract of Calendula oficinalis in rat," Basic Clin. Neurosci., 3, No. 5, 45-48 (2012).

11. S. Shahidi and P. Pahlevani, "Antinociceptive effects of an extract of Securigera securidaca and their mechanisms in mice," Neurophysiology, 45, No. 1, 34-38 (2013).

12. M. Mahmoudi, S. Mohammadi, and S. Shahidi, "Antinociceptive effect of hydroalcoholic leaf extract of Hedera helix in male rat," Sci. J. Hamadan Univ. Med. Sci., 20, No. 2, 119-125 (2013).

13. S. Hao, O. Takahata, and H. Iwasaki, "Intrathecal endomorphin-1 produces antinociceptive modulated by alpha 
2 -adrenoceptors in the rat tail flick, tail pressure and formalin tests," Life Sci., 66, No. 15, 195-204 (2000).

14. C. C. Barua, A. Talukdar, S. A. Begum, et al., "Antinociceptive activity of methanolic extract of leaves of Achyranthes aspera Linn.(Amaranthaceae) in animal models of nociception," Ind. J. Exp. Biol., 48, No. 8, 817-821 (2010).

15. R. Deraedt, S. Jouquey, F. Delevallée, and M. Flahaut, "Release of prostaglandins $\mathrm{E}$ and $\mathrm{F}$ in an algogenic reaction and its inhibition," Eur. J. Pharmacol., 61, No. 1, 17-24 (1980).

16. N. Shekhawat and R. Vijayvergia, "Investigation of antiInflammatory, analgesic and antipyretic properties of Madhuca indica GMEL," Eur. J. Inflamm., 8, No. 3, 165-171 (2010).

17. M. J. Alcaraz and J. R. Hoult, "Actions of flavonoids and the novel anti-inflammatory flavone, hypolaetin-8-glucoside, on prostaglandin biosynthesis and inactivation," Biochem. Pharmacol., 34, No. 14, 2477-2482 (1985).

18. B. Isacchi, R. Iacopi, M. C. Bergonzi, et al., "Antihyperalgesic activity of verbascoside in two models of neuropathic pain," $J$. Pharm. Pharmacol., 63, No. 4, 594-601 (2011).

19. R. Scogin, "The distribution of acteoside among angiosperms," Biochem. Sys. Ecol., 20, No. 5, 477-480 (1992).

20. E. Küpeli, F. P. Sahin, E. Yeşilada, et al., "In vivo antiinflammatory and antinociceptive activity evaluation of phenolic compounds from Sideritis stricta," Z. Naturforsch. C., 62, Nos. 7/8, 519-525 (2007). 